\title{
Potentiality of a fruit peel (banana peel) toward abatement of fluoride from synthetic and underground water samples collected from fluoride affected villages of Birbhum district
}

\author{
Naba Kumar Mondal ${ }^{1} \cdot$ Arunabha Roy $^{1}$ \\ Received: 11 May 2017 / Accepted: 21 May 2018 / Published online: 29 May 2018 \\ (c) The Author(s) 2018
}

\begin{abstract}
Contamination of underground water with fluoride $(\mathrm{F})$ is a tremendous health hazard. Excessive $\mathrm{F}(>1.5 \mathrm{mg} / \mathrm{L})$ in drinking water can cause both dental and skeletal fluorosis. A fixed-bed column experiments were carried out with the operating variables such as different initial F concentrations, bed depths, $\mathrm{pH}$ and flow rates. Results revealed that the breakthrough time and exhaustion time decrease with increasing flow rate, decreasing bed depth and increasing influent fluoride concentration. The optimized conditions are: $10 \mathrm{mg} / \mathrm{L}$ initial fluoride concentration; flow rate $3.4 \mathrm{~mL} / \mathrm{min}$, bed depth 3.5 and $\mathrm{pH}$. The bed depth service time model and the Thomas model were applied to the experimental results. Both the models were in good agreement with the experimental data for all the process parameters studied except flow rate, indicating that the models were appropriate for removal of $\mathrm{F}$ by natural banana peel dust in fix-bed design. Moreover, column adsorption was reversible and the regeneration was accomplished by pumping of $0.1 \mathrm{M} \mathrm{NaOH}$ through the loaded banana peel dust column. On the other hand, field water sample analysis data revealed that $86.5 \%$ fluoride can be removed under such optimized conditions. From the experimental results, it may be inferred that natural banana peel dust is an effective adsorbent for defluoridation of water.
\end{abstract}

Keywords Banana peel · Fluoride $\cdot$ Column study $\cdot$ Dental and skeletal fluorosis $\cdot$ Regeneration

\section{Introduction}

Due to rapid industrialization, huge quantity of pollutants discharges in to the environment. Fluorine is one such pollutant that threatens living organisms, in particular humans (Koilraj and Kannan 2013). Fluoride is a strongly electronegative element, and its presence in drinking water is essential for human health (Chen et al. 2012). However, excess consumption of fluoride can lead to both dental and skeletal fluorosis (Kierdorf et al. 2016; Death et al. 2015). Previous literature (Mohan et al. 2012) demonstrated that more than 200 million people worldwide are affected by fluoridecontaminated drinking water with very high concentration. As per the guideline adopted by WHO (2011) and Bureau of Indian standard (BIS 1991), the concentration of fluoride

Naba Kumar Mondal

nkmenvbu@gmail.com

Environmental Chemistry Laboratory, Department of Environmental Science, The University of Burdwan, Bardhaman, West Bengal, India in drinking water should not exceed beyond $1.5 \mathrm{mg} / \mathrm{L}$. Many technologies such as precipitation, ion exchange, electrolysis have been developed. However, all the above techniques are not cost-effective. These are high maintenance charge and not easy to regenerate. But there is another technique, called adsorption which is an important cost-effective technique widely used in most of the developing country for removal of fluoride from drinking water (Mondal and Roy 2015).

Pertinent literature highlighted that many cost-effective adsorbents such as sugarcane bagasse, tea waste ash, aluminum impregnated potato plant ash and coconut fiber ash, lemon leaf dust, banana peel dust, rice husk carbon, tea ash, silica gel, egg shell dust, calcareous soil, coconut fiber, banana peel have been used for removal of fluoride from contaminated drinking water (Ghosh et al. 2016; Mondal et al. 2015; Bhaumok et al. 2013; Mondal et al. 2012a, b, c, d; Bhaumik et al. 2012; Bhaumik and Mondal 2014a, b). But none of the above adsorbents showed excellent removal performance along with high adsorption capacity. Therefore, it is prime important to synthesize an efficient and costeffective adsorbent for decontamination of fluoride from the aqueous medium (Chen et al. 2012). 
Adsorption technique normality processed through batch and column process (Tor et al. 2009). But in batch process, all the operating variables remain constant while one variable changes at a time, and the process is costly and timeconsuming. Therefore, column separation process may be the suitable one for defluoridation of domestic as well as community level. In our previous work, we have used the banana peel for removal of fluoride through batch process followed by response surface optimization techniques. Very recently, we have tried with another variety of banana peel for the same purposes. But, we cannot achieve to reach the desired level.

Bananas are a popular fruit consumed worldwide with an early production of over 145 million tonnes in 2011. Once the peel is removed, the fruit can be raw or cooked and peel is generally discarded. On average, banana peel contains 6-9\% dry matter of protein and $20-30 \%$ fiber. Normally, the ripe banana peels contains $30 \%$ free sugar and $15 \%$ more starch than green banana peels. Moreover, banana peel has many biomolecules such as lignin, cellulose and hemicellulose with variety of active functional groups (carboxyl, hydroxyl, amine, etc.) which suppose to bind the pollutants (Deshmukh et al. 2017; Kumar et al. 2011).

The present work is aimed at synthesizing an efficient and economical adsorbent using banana peel toward removal of fluoride from water through column study. Finally, the prepared adsorbent was used for removal of fluoride from field samples which was collected from the fluoride affected villages of Birbhum district, West Bengal.

\section{Materials and methods}

\section{Preparation of banana peel dust}

The raw waste banana peels (Musa paradisiaca) were collected from nearby fruits stall of Burdwan town, West Bengal. After collection, peels were thoroughly washed with distilled water followed by washing with de-ionized water and dried in hot air oven at $50{ }^{\circ} \mathrm{C}$ for $12 \mathrm{~h}$. The dried peels were cut into small pieces and again dried in hot air oven maintaining $60{ }^{\circ} \mathrm{C}$ temperatures for $24 \mathrm{~h}$. The dried banana peels were ground using kitchen grinder to get the desired particle size $(200 \mu \mathrm{m})$, the powder form of banana peel was stored in airtight container, the physico-chemical analysis was done, and the results are depicted in Table 1.

\section{Point of zero charge $\left(\mathrm{pH}_{\mathrm{zPC}}\right)$}

Zero point charge of the banana peel was determined by following the solid addition method (Mondal 2010). Initially, a series of conical flasks were taken with $50 \mathrm{~mL}$ of 0.1 (M) $\mathrm{KNO}_{3}$ solutions in each flask along with $0.1 \mathrm{~g}$ banana peel.
Table 1 Physical characteristics of banana peel

\begin{tabular}{lc}
\hline Parameter & Values \\
\hline $\mathrm{pH}$ & 6.59 \\
Conductivity $(\mathrm{mS} / \mathrm{cm})$ & 190 \\
Specific gravity & 2.66 \\
Bulk density $(\mathrm{g} / \mathrm{cc})$ & 0.384 \\
Particle density $(\mathrm{g} / \mathrm{cc})$ & 0.138 \\
Porosity $(\%)$ & 178.26 \\
Moisture content $(\%)$ & 2.98 \\
$P_{\text {zpc }}^{\mathrm{H}}$ & 5.63 \\
Dry matter & 89.73 \\
Crude fiber & 10.33 \\
Ash & 17.94 \\
BET surface area & $23.983 \mathrm{~m}^{2} / \mathrm{g}$ \\
\hline
\end{tabular}

The $\mathrm{pH}$ of the $0.1(\mathrm{M}) \mathrm{KNO}_{3}$ solutions was adjusted by using $0.05(\mathrm{~N}) \mathrm{HNO}_{3}$ and $0.1(\mathrm{~N}) \mathrm{KOH}$ solutions. After thoroughly shaking $(24 \mathrm{~h})$, the $\mathrm{pH}$ of the final solutions was recorded and a graph was constructed by $\mathrm{pH}$ versus $\Delta \mathrm{pH}$.

\section{Column study}

\section{Thomas model}

The Thomas model can be used to predict the breakthrough curve and the maximum adsorption capacity of the banana peel in a fixed-bed operation. The linearized form of Thomas model can be presented in Eq. (1):

$\ln \left(\frac{C_{0}}{C-1}\right)=\frac{K_{\mathrm{Th}} q_{0} X}{Q}-\frac{K_{\mathrm{Th}} C_{0} t}{Q}$

where $X$ is the amount of sorbent taken in the column $(\mathrm{g})$ and $Q$ is the effluent flow rate $(\mathrm{mL} / \mathrm{min})$. The kinetic coefficient $K_{\mathrm{Th}}$ and the adsorption capacity of the bed $q_{0}$ for the defluoridation process can be calculated by plotting $\ln \left(C_{0} / C-1\right)$ versus $t$.

\section{Bed depth service time model (BDST)}

It is familiar that BDST model provide a simplest approach and suitable prediction of absorber performance (Al-Degs et al. 2009). BDST model basically provides a relationship between column bed depth, $X$ and service time $t$. However, this particular model also focused on the estimation of characteristic parameters such as maximum adsorption capacity $\left(N_{0}\right)$ kinetic constant $(K)$. Moreover, this model considers one valuable assumption that is the adsorption rate is proportional to residual capacity of the sorbent and the concentration of the sorbing species. The relationship of service time 
with process conditions and operating parameters is given as Eq. (2):

$\ln \left(\left[\frac{C_{0}}{C_{b}}-1\right]\right)=\ln \left(\exp \left(\frac{K X N_{0}}{v}\right)-1\right)-K C_{0} t$

A linear relationship between bed depth and service time may be given by Eq. 3 (Al-Degs et al. 2009)

$t=\frac{N_{0} X}{v C_{0}}-\frac{1}{K C_{0}} \ln \left(\frac{C_{0}}{C_{b}}-1\right)$

where $C_{0}$ is the initial concentration of solute $(\mathrm{mg} / \mathrm{L}), C_{\mathrm{b}}$ the desired concentration of solute at breakthrough $(\mathrm{mg} / \mathrm{L})$, $K$ the adsorption rate constant $(\mathrm{L} / \mathrm{mg} / \mathrm{h}), N_{0}$ the adsorption capacity $(\mathrm{mg} / \mathrm{L}), X$ the bed depth of column $(\mathrm{cm}), v$ the linear flow velocity of feed to bed $(\mathrm{cm} / \mathrm{h})$, and $t$ the service time of column under above conditions (hrs). Equation (4) can be rewritten in the form of a straight line.

$T=a X-b$

where ' $a$ ' is slope of BDST line $\left(a=\frac{N_{0}}{v C_{0}}\right)$ and the intercept of this equation represents as Eq. (5):

$b=\frac{1}{K C_{0}} \ln \left(\frac{C_{0}}{C_{b}}-1\right)$

Thus, $N_{0}$ and $K$ can be evaluated from slope (a) and the intercept (b) of the plot of t versus $X$, respectively.

\section{Column regeneration study}

In order to activate the exhausted column, regeneration experiments were conducted by using 0.1 (M) NaOH solutions. The desorption experiments were conducted with the flow rate $2 \mathrm{~mL} / \mathrm{min}$. After passing $100 \mathrm{~mL}$ of 0.1 (M) $\mathrm{NaOH}$, the entire column bed was washed with double distilled water. Finally, the regenerated column was then used for the next cycle of column adsorption.

The desorption efficiency $E_{\mathrm{D}}$ was calculated by the following Eq. (6) (Zhu et al. 2007)

$E_{\mathrm{D}}=\frac{M_{\mathrm{D}} \times 100}{\left[\left(q_{\mathrm{E}}^{\mathrm{m}}+M_{\mathrm{A}}\right)\right]}$

where $M_{\mathrm{D}}$ is desorption fluoride amount (mg) eluted by desorption solution $(0.3 \mathrm{M} \mathrm{NaOH}) . q_{\mathrm{E}}$ and $\mathrm{m}$ are the capacity at exhaustion point (L) and adsorbent dose, respectively, and $M_{\mathrm{A}}$ is the fluoride amount $(\mathrm{mg})$ retained in the column.

\section{Analytical procedure}

Effluent solution was collected at regular interval, and their concentrations were measured (Thermo Orion, 4 star); $\mathrm{pH}$ of the experimental solution was measured by using $\mathrm{pH}$ meter
(Systronic 206). The breakthrough curves were constructed by Origin software (Version 6.0).

\section{Dental and skeletal fluorosis study}

Primary school children aged between 5-10 years were selected from fluoride affected villages of Birbhum district, West Bengal. Dental fluorosis was examined by a trained examiner who held a master degree in dentistry with the help of Dean index (Dean 1934). Skeletal fluorosis was assessed by clinical symptoms and physical exercise (Susheela and Bhatnagar 2002; Shashi et al. 2008).

\section{Results and discussion}

\section{Adsorbent characterization}

Preparation of banana peel dust was subjected to $\mathrm{pH}_{\mathrm{ZPC}}$ and SEM study for understanding the zero point charge and surface morphology (HITACHI-S-530, Scanning Electron Microscope and ELKO Engineering, accelerating voltage of $20.0 \mathrm{kV}$ ) and surface chemistry of the banana peel was assessed by FTIR (BRUKER, Tensor 27). The zero point charge of the banana peel was recorded as 5.63 (Fig. 1), and from the scanning micrograph it is clear that the surface of the banana peel dust is absolutely rough in nature and huge heterogeneity (Fig. 2a). However, after F removal, the surface of banana peel is smooth with less degree of heterogeneity (Fig. 2b). The Fourier transformer infrared spectroscopy clearly revealed that it has sharp peaks at 3340, 2890 and $1741 \mathrm{~cm}^{-1}$ which corresponds the functional groups hydroxyl $(-\mathrm{OH})$, alkyl $\mathrm{C}-\mathrm{H}$, and carboxyl $(-\mathrm{COOH})$, respectively (Fig. 3). Therefore, it is expected that the functional groups such as $-\mathrm{OH}$ and $-\mathrm{COOH}$ may interact with fluoride during adsorption.

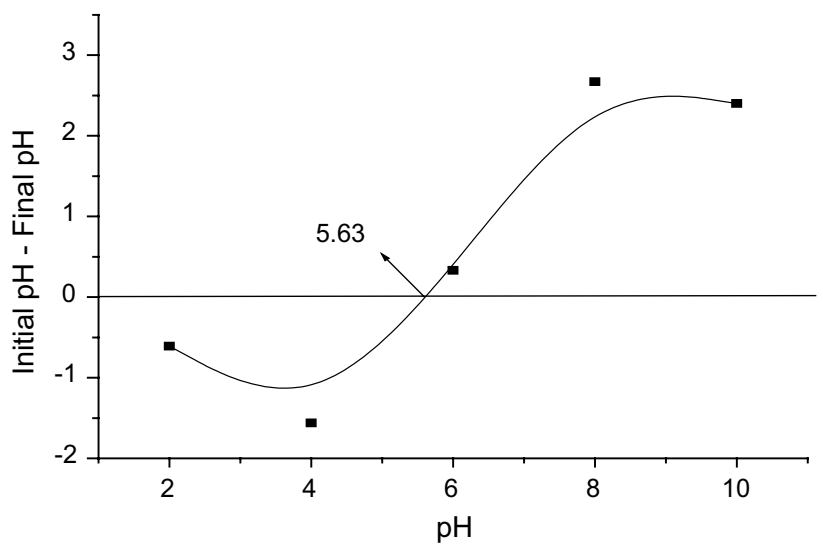

Fig. 1 ZPC of Banana peel dust 


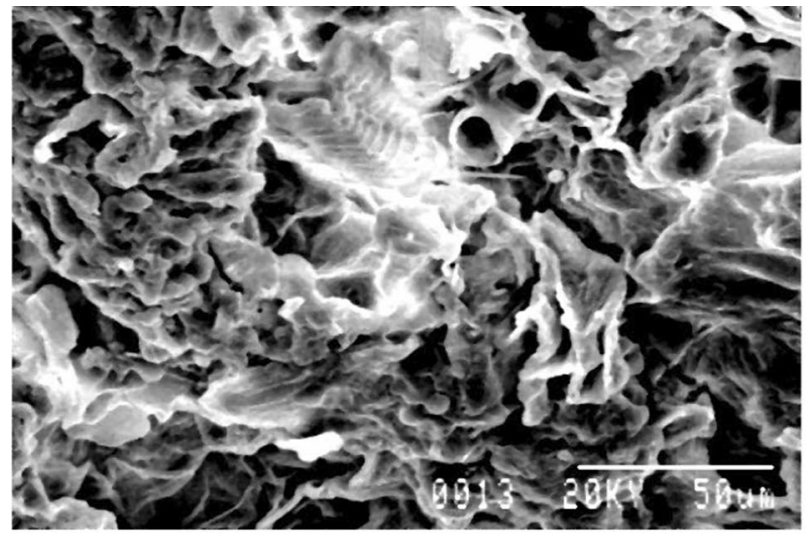

(a)

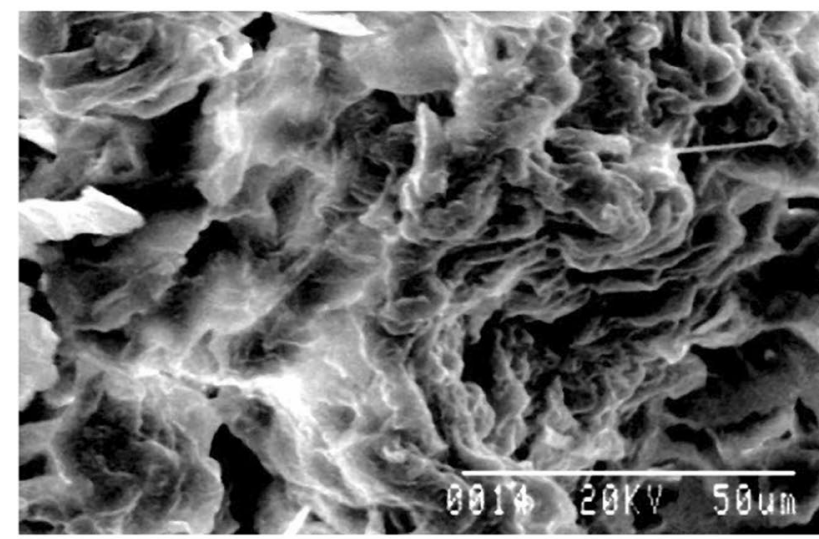

(b)

Fig. 2 Scanning electron microscopy of banana peel: a before passing fluoride solution ( $\times 1500$ magnification), $\mathbf{b}$ after passing fluoride solution $(\times 1500$ magnification $)$

\section{The effect of initial concentration of solution on breakthrough curve}

Three different initial concentrations $(1.5,10,35 \mathrm{mg} / \mathrm{L})$ were used in this study. The values were chosen because they were considered to fairly represent fluoride concentration range in most groundwater. The bed mass and flow velocity of the present experiment have been taken as $2 \mathrm{~g}$ and $3.4 \mathrm{~mL} / \mathrm{min}$, respectively. The breakthrough curves (BTCs) obtained from the experimental investigation of the effect of the initial concentration on fluoride removal are depicted in Fig. 4. From Fig. 4 it is clear that higher the fed concentration, the steeper is the breakthrough curve and smaller is the breakthrough time. The adsorbent exhaustion rates (AER) (bed volume (BV) in parenthesis) were computed and found to be 0.046(3.31), 0.023(6.16) and 0.009(15.39) $\mathrm{g} / \mathrm{L}$ for the initial concentrations of 35,10 and $1.5 \mathrm{mg} / \mathrm{L}$, respectively (Table 2). As the concentration increase, the driving force for adsorption increases and the active sites are consumed faster. The results also highlighted that both saturation rate and breakthrough time change with changing influent concentration (Goel et al. 2005). This is because, at higher concentration, the active sites of the adsorbent get saturated very quickly (Mondal et al. 2013).

\section{The effect of flow rate on breakthrough curve}

Steeper breakthrough curve was obtained at higher flow rates (Fig. 5). Further it was studied that the steepness of the breakthrough curve reduces with decreasing flow rates i.e., increase in breakthrough time. The breaks through curves appeared steeper at higher flow rates may be due to faster movement of adsorption zone along the bed aiding its quick saturation (Sulaiman et al. 2009; Tor et al. 2009). Again the variation in the slope of the breakthrough curve
Fig. 3 FTIR spectrum of banana peel dust (BPD)

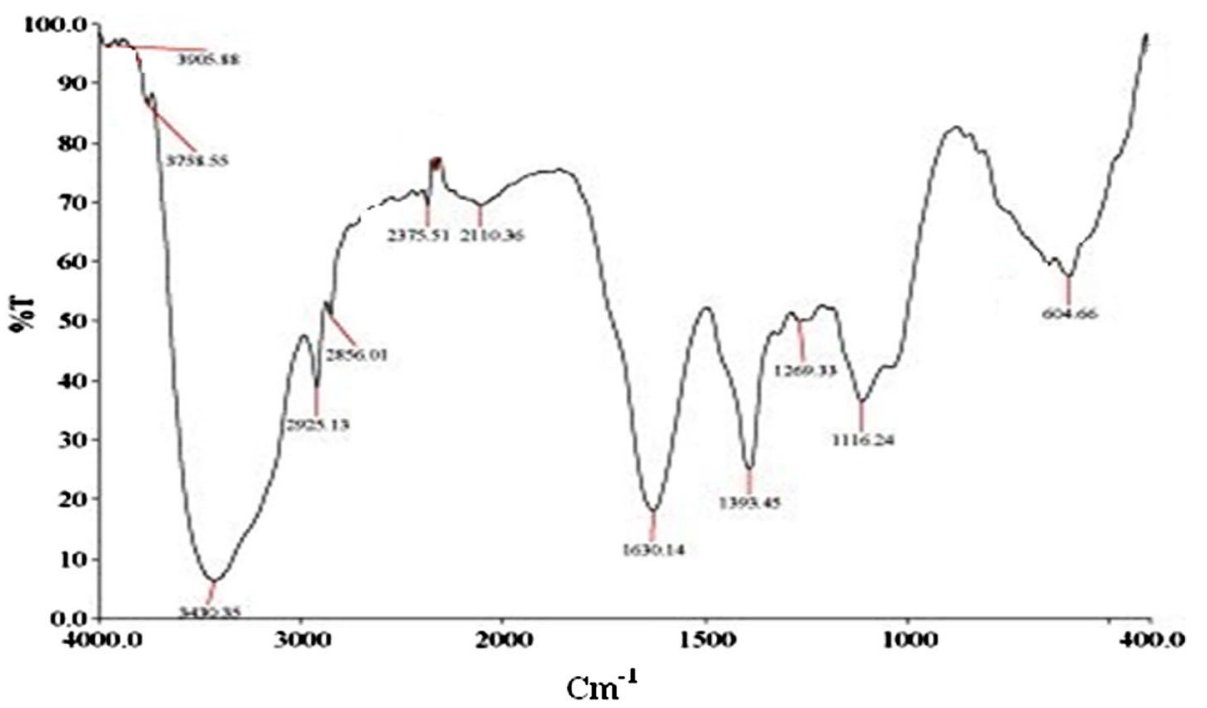

年 KACST والتقني 


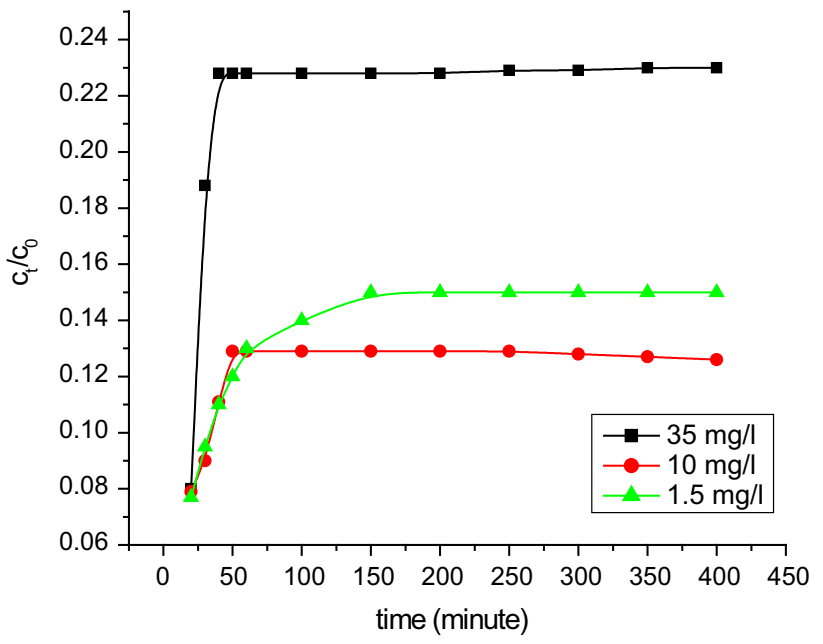

Fig. 4 Breakthrough curve of the effect of different influent concentration on fluoride adsorption onto banana peel $(v=3.4 \mathrm{ml} / \mathrm{min}$, $Z=0.9 \mathrm{~cm}, \mathrm{pH}=5$ )

and adsorption capacity may be explained on the basis of mass transfer fundamentals. The reason is that at higher flow rate the rate of mass transfer increases, i.e., the amount of fluoride adsorbed onto unit bed height (mass transfer zone) increased with increasing flow rate leading to faster saturation at higher flow rate (Talnikar et al. 2004). The increase in adsorption capacity (both up to breakthrough and exhaust) of banana peel was more pronounced at the flow rate of $1.7 \mathrm{~mL} / \mathrm{min}$, whereas the effect is almost negligible at the flow rate of $8.0 \mathrm{~mL} / \mathrm{min}$. The rate constant, $K_{\mathrm{Th}}$, increased with increasing the flow rate which indicates that the mass transport resistance decreases (Tor et al. 2009). The different bed volumes (BV) of water processed at breakthrough curve were found to be $6.02,30.08$, and $176.93 \mathrm{~L}$ for $1.7,3.4$, and $8.0 \mathrm{~mL} / \mathrm{min}$, respectively (Table 2). The increase in volume processed with an increased in velocity can be attributed to reduced influence of external mass transfer resistance (Ghribi and Chlendi 2011). The AER values for this respective flow rate are $0.029,0.006$ and $0.001 \mathrm{~g} / \mathrm{mL}$, respectively.

\section{The effect of $\mathrm{pH}$ on breakthrough curve}

The breakthrough curves for different $\mathrm{pH}$ are shown in Fig. 6. The $\mathrm{pH}$ of the aqueous solution has been recognized as one of the most important factors influencing adsorption kinetics due to its direct influence on the surface properties of the adsorbent (Memon et al. 2008). As shown in Fig. 6, where the value of $\mathrm{pH}$ was 5, the value of $C_{\mathrm{t}} / C_{0}$ reached 0.042 in $30 \mathrm{~min}$. But the breakthrough curve of the $\mathrm{pH} 7.0$ and 9.0 was not more than 0.045 and 0.109 in the different time periods, respectively. With a decrease in $\mathrm{pH}$ in the influent, the breakthrough curves shifted from left to right, which indicates higher removal of fluoride. It would spend more time reaching the saturation, and the efficiency of biosorption was much higher (Ma et al. 2008). The F ion binding could be attributed to several mechanisms such as ion exchange, complexation, electrostatic attraction and precipitation. For banana peel, ion exchange has been considered as a main mechanism responsible for pollutant sequestering (Sheng et al. 2004). The result suggests that with the decrease in $\mathrm{pH}$, under experimental condition, the adsorption capacities increase (Table 2). So the removal of fluoride from aqueous solution was more efficient at lower initial $\mathrm{pH}$ value.
Table 2 Summary of pertinent results at breakthrough point of banana peel

\begin{tabular}{lclll}
\hline Parameters & $\begin{array}{l}\text { Service time } \\
(\mathrm{min}) t_{\mathrm{b}}\end{array}$ & $\begin{array}{l}\text { Adsorption capacity } \\
(\mathrm{mg} / \mathrm{g}) q_{\mathrm{b}}\end{array}$ & $\begin{array}{l}\text { Bed volume pro- } \\
\text { cessed (BV) }\end{array}$ & AER (g/ml) \\
\hline Adsorbent mass (g) & & & & \\
2 & 40 & 0.405 & 12.03 & 0.015 \\
4 & 100 & 0.429 & 15.92 & 0.012 \\
8 & 250 & 0.449 & 19.34 & 0.009 \\
$\mathrm{pH}$ & & & & \\
5.0 & 30 & 0.479 & 9.02 & 0.020 \\
7.0 & 60 & 0.477 & 18.05 & 0.010 \\
9.0 & 300 & 0.441 & 90.23 & 0.002 \\
Different flow (ml/min) & & & & \\
1.7 & 40 & 0.495 & 6.02 & 0.029 \\
3.4 & 100 & 0.477 & 30.08 & 0.006 \\
8.0 & 250 & 0.466 & 176.93 & 0.001 \\
Initial concentration (mg/L) & & & & \\
35.0 & 30 & 0.014 & 3.31 & 0.046 \\
10.0 & 60 & 0.109 & 6.16 & 0.023 \\
1.5 & 150 & 0.419 & 15.39 & 0.009 \\
\hline
\end{tabular}




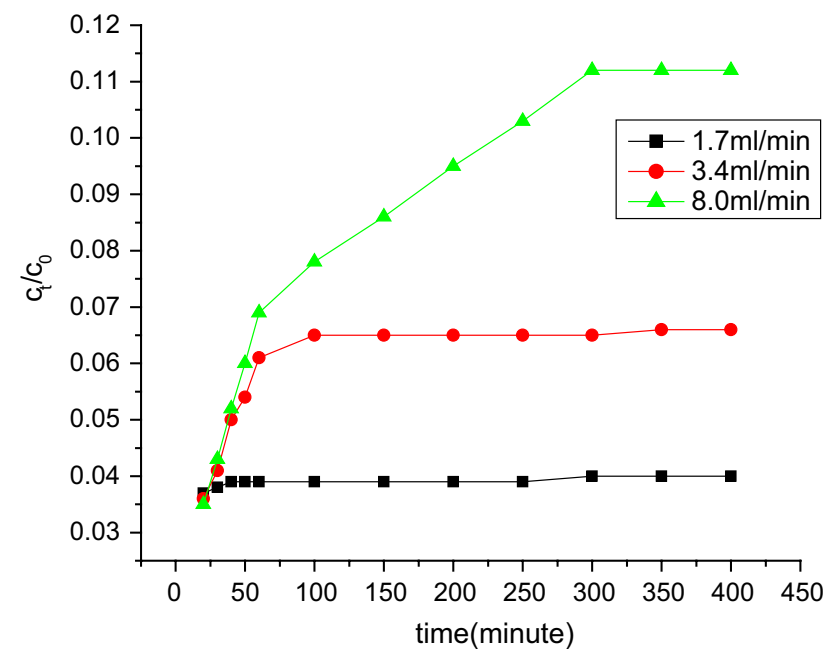

Fig. 5 Breakthrough curve of the effect of different flow rate on fluoride adsorption onto banana peel dust $\left(C_{0}=10.0 \mathrm{mg} / \mathrm{L}, Z=0.9 \mathrm{~cm}\right.$, $\mathrm{pH}=5$ )

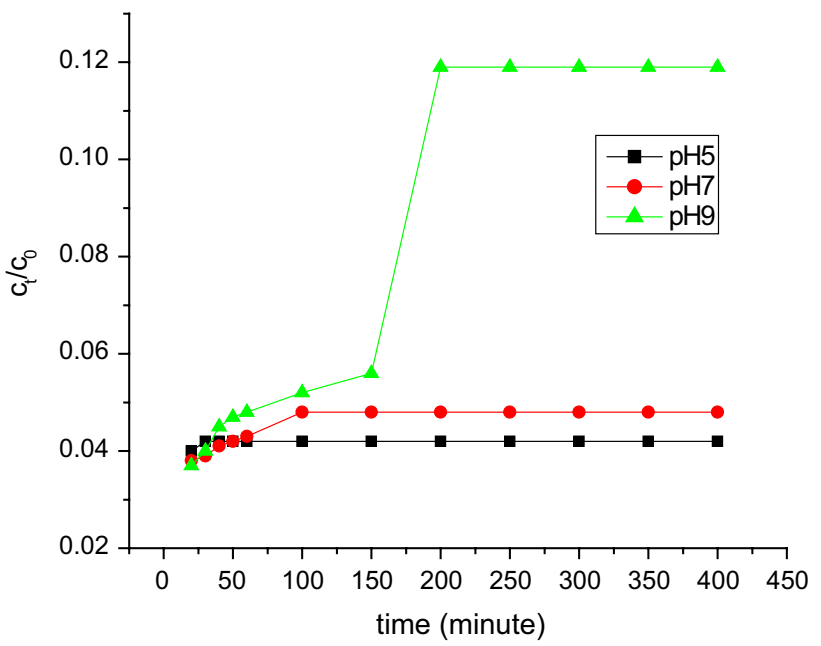

Fig. 6 Breakthrough curve of the effect of different $\mathrm{pH}$ on fluoride adsorption onto banana peel dust $\left(v=3.4 \mathrm{ml} / \mathrm{min}, C_{0}=10.0 \mathrm{mg} / \mathrm{L}\right.$, $Z=2 \mathrm{~g}$ )

The AER for different $\mathrm{pH}$ are 0.0196, 0.098, $0.020 \mathrm{~g} / \mathrm{mL}$, respectively. There are many reasons which may be attributed toward the fluoride adsorption behavior of the sorbent relative to solution $\mathrm{pH}$. At lower $\mathrm{pH}$, the surface of banana peel may get positively charged, which enhances the negatively charged fluoride ion through electrostatic force of attraction (Han et al. 2007). Almost similar results reported by Paudyal et al. (2013) for removal of $\mathrm{F}$ using a fixed-bed column packed with $\mathrm{Zr}$ (IV) loaded dried orange juice residue.

\section{The effect of different bed depths on the breakthrough curve}

Keeping the initial concentration of fluoride, flow rate and $\mathrm{pH}$ of the solution constant and with varying bed depth, the number of active sites available for sorption and the contact time of solute with the adsorbent were determined. Figure 7 shows the BTs obtained upon varying the quantity of adsorption media between 2,4 and $8 \mathrm{~g}$. From the BTCs, the $t_{b}$ and $q_{b}$ were determined and are summarized in Table 2. From the bed depth study, it was found that as the bed height increases, adsorbate had more time to contact with banana peel dust that resulted in higher removal efficiency of fluoride ion in column (Fig. 7). So, the higher bed depth results in a decrease in the solute concentration in the effluent at the same time. The slope of breakthrough curve decreased with increasing bed height, which resulted in a broadened mass transfer zone. High uptake was observed with highest bed depth $3.7 \mathrm{~cm}$ height due to an increase in the surface area of biosorbent, which provided more binding sites for the sorption (Vadivelan and Kumar 2005). Almost similar results were reported by Paudyal et al. (2013) and Mondal et al. (2013) for F removal by dried orange juice residue and sugarcane charcoal. The different bed volumes (BV) of water processed at breakthrough curve were found to be $12.03,15.92,19.34$ $\mathrm{L}$, and the AER value was found to be $0.0145,0.0117$, $0.0094 \mathrm{~g} / \mathrm{mL}$ for 2,4 and $8 \mathrm{~g}$ of banana peel dust adsorbent, respectively.

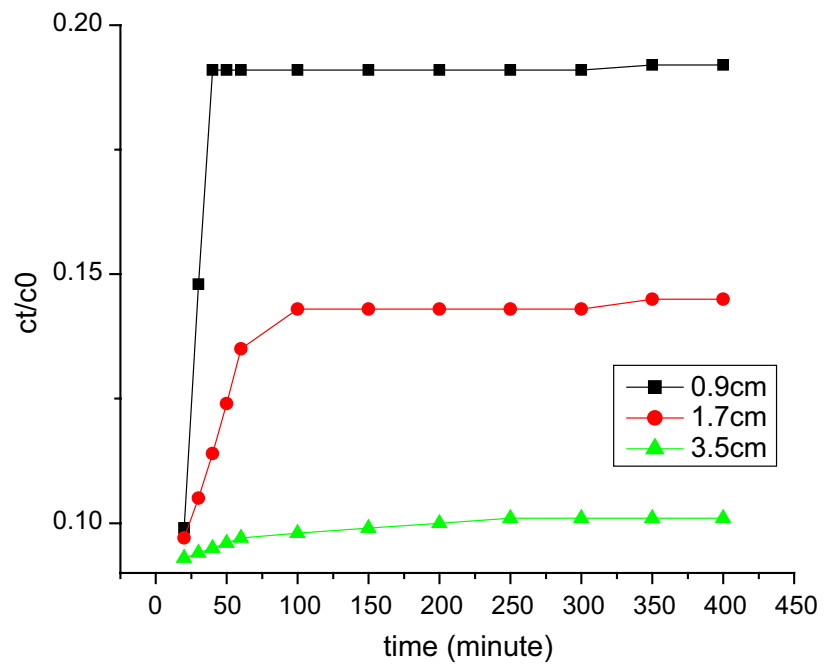

Fig. 7 Breakthrough curve of the effect of different bed depth on fluoride adsorption onto banana peel dust $(v=3.4 \mathrm{ml} / \mathrm{min}$, $C_{0}=10.0 \mathrm{mg} / \mathrm{L}, \mathrm{pH}=5$ ) 
Table 3 Calculated constants of Thomas model at different conditions using linear regression analysis

\begin{tabular}{lllllrl}
\hline $\mathrm{pH}$ & $Z(\mathrm{~cm})$ & $v(\mathrm{ml} / \mathrm{min})$ & $C_{0}(\mathrm{mg} / \mathrm{L})$ & $K_{\text {th }}(\mathrm{ml} / \mathrm{min} / \mathrm{mg})$ & $q_{0}(\mathrm{mg} / \mathrm{g})$ & $R^{2}$ \\
\hline 5 & 3.5 & 3.4 & 10 & 55.12 & 98.26 & 0.999 \\
7 & 3.5 & 3.4 & 10 & 55.12 & 98.26 & 0.999 \\
9 & 3.5 & 3.4 & 10 & 55.12 & 98.26 & 0.999 \\
5 & 0.9 & 3.4 & 10 & 7.80 & 3.76 & 0.996 \\
5 & 1.7 & 3.4 & 10 & 7.80 & 1.88 & 0.996 \\
5 & 3.5 & 3.4 & 10 & 7.80 & 0.94 & 0.996 \\
5 & 3.5 & 1.7 & 10 & 12.61 & 29.81 & 0.775 \\
5 & 3.5 & 3.4 & 10 & 25.22 & 59.61 & 0.775 \\
5 & 3.5 & 8.0 & 10 & 59.34 & 140.27 & 0.775 \\
5 & 3.5 & 1.7 & 1.5 & 43.58 & 8.15 & 0.996 \\
5 & 3.5 & 1.7 & 10 & 6.54 & 8.15 & 0.996 \\
5 & 3.5 & 1.7 & 35 & 1.87 & 8.15 & 0.996 \\
\hline
\end{tabular}

Fig. 8 BDST model at breakthrough curve in fixed-bed column for $\mathrm{F}$ adsorption by banana peel

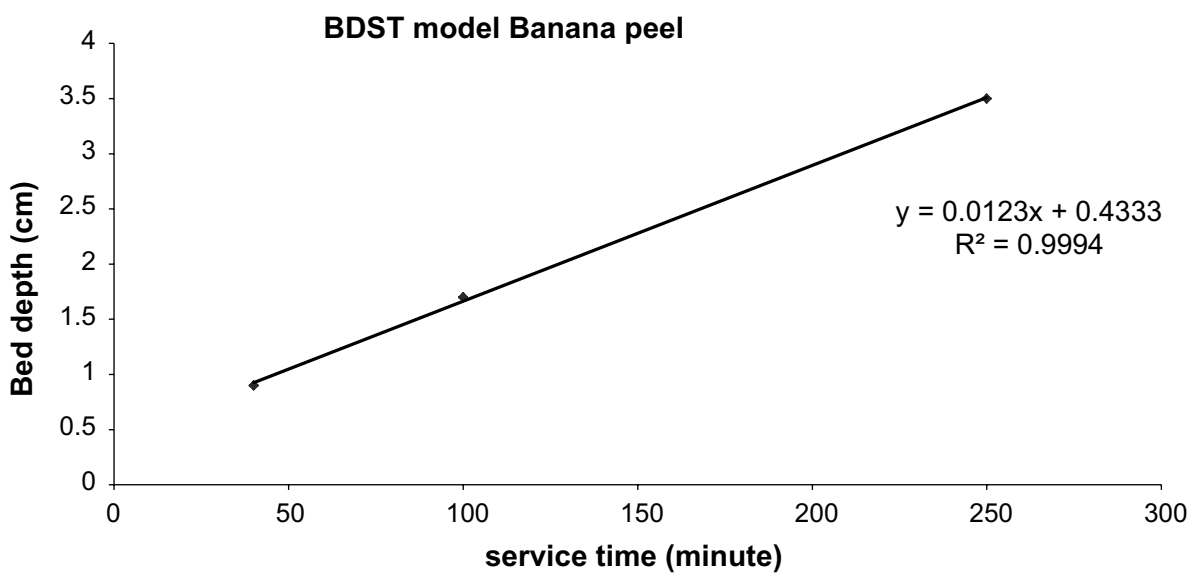

Table 4 Calculated constants of BDST model for the adsorption of fluoride by banana peel dust using linear regression analysis

\begin{tabular}{llllll}
\hline$C_{t} / C_{0}$ & $a(\mathrm{~min} / \mathrm{cm})$ & $b(\mathrm{~min})$ & $K_{\mathrm{a}}(1 / \mathrm{mg} / \mathrm{min})$ & $N_{0}(\mathrm{mg} / \mathrm{l})$ & $R^{2}$ \\
\hline 0.0101 & 0.0123 & 0.4333 & 0.005 & 0.4182 & 0.9994 \\
\hline
\end{tabular}

$C_{0}=10.0 \mathrm{mg} / \mathrm{L}, v=3.4 \mathrm{ml} / \mathrm{min}$

\section{Modeling of breakthrough curve}

The entire experimental column study has been fitted with Thomas model, results revealed that all the operating variables are well acquainted with Thomas model, and goodness of the fit of the model $\left(R^{2}\right)$ is very high except variation of flow rate (Table 3 ). A plot of service time $(t)$ versus bed depth $(X)$ at a flow rate of $3.4 \mathrm{~mL} / \mathrm{min}$ is shown in Fig. 8 . The equation of the linear relationship was obtained with $R^{2}$ above 0.999 . This indicated the validity of the BDST model for present column system. The calculated adsorption capacity $\left(N_{0}\right)$ and the rate constant $(K)$ are $0.418 \mathrm{mg} / \mathrm{L}$ and $5 \times 10^{-3} \mathrm{~L} / \mathrm{mg} / \mathrm{min}$, respectively (Table 4). The advantage of the BDST model is that any experimental test can be reliably
Table 5 Column regeneration parameters for NBP column

\begin{tabular}{lll}
\hline Regeneration cycle & $\begin{array}{l}\text { Percentage of desorption } Q_{\mathrm{E}} \\
(\mathrm{mg} / \mathrm{g})(\%)\end{array}$ & $E_{\mathrm{D}}(\%)$ \\
\hline 1 & 84 & 2.091 \\
2 & 72 & 1.321 \\
3 & 54 & 0.694 \\
\hline
\end{tabular}

Adsorption operation constant-initial fluoride concentration: $8 \mathrm{ml} /$ $\min ; Z=0.9 \mathrm{~cm} ; \mathrm{pH}=5 ; C_{0}=10 \mathrm{mg} / \mathrm{L}$. Desorption condition-desorption solution $0.1 \mathrm{M} \mathrm{NaOH}$, solution flow rate $2 \mathrm{ml} / \mathrm{min}$

scaled up to other flow rates without further experimental runs.

\section{Regeneration study}

After regeneration of the exhausted column, it has been found that desorption gradually decreases from first to second and second to third cycles. The calculated column desorption parameters are listed in Table 5. From Table 5, it is clear that $E_{D}$ value decreases with consecutive cycles of 
desorption (Tor et al. 2009). This is probably due to the loss of adsorption capability of banana peel dust column.

\section{Defluoridation from field sample}

Forty three (43) tube well water samples were collected from the severally fluoride affected villages of Birbhum district, West Bengal. The children aged between 5 and 10 years were selected for understanding the status of dental and skeletal fluorosis (Fig. 9). From the data (data not shown), it is clear that about $63 \%$ boys and $48 \%$ girls were severally affected by dental fluorosis (Fig. 9). However, 18\% boys and $12 \%$ of girls were affected by skeletal fluorosis (Fig. 9). The physico-chemical analysis of the field samples is presented in Table 6. From Table 6 it is found that the highest fluoride level in the affected areas is $9.89 \mathrm{mg} / \mathrm{L}$. Moreover, for field sample defluoridation study, highest fluoride containing tube well water $(9.89 \mathrm{mg} / \mathrm{L})$ was selected and it was recorded that about $86.5 \%$ removal can be achieved through standardized column study $\left(v=3.4 \mathrm{~mL} / \mathrm{min}, C_{0}=9.89, \mathrm{pH}\right.$ $=5, Z=3.7 \mathrm{~cm}$ ).

\section{Conclusions}

Present finding highlights the removal of fluoride from both synthetic and field samples using banana peel dust through column study. The surface morphology of the banana peel dust was assessed by SEM study, and the active functional group was evaluated by FTIR study (Table 7). Fluoride adsorption results highlighted that
Table 6 Physico-chemical characteristics of ground water

\begin{tabular}{lc}
\hline Parameters & Values \\
\hline Conductivity $(\mu \mathrm{S} / \mathrm{cm})$ & $113 \pm 2.07$ \\
Hardness $\left(\mathrm{mg} / \mathrm{L}, \mathrm{CaCO}_{3}\right)$ & $178 \pm 3.11$ \\
Chlorine $(\mathrm{mg} / \mathrm{L})$ & $12.3 \pm 0.71$ \\
Nitrate $(\mathrm{mg} / \mathrm{L})$ & $9.3 \pm 0.06$ \\
Sulfate $(\mathrm{mg} / \mathrm{L})$ & $0.81 \pm 0.013$ \\
Fluoride $(\mathrm{mg} / \mathrm{L})$ & $9.89 \pm 0.33$ \\
$\mathrm{pH}$ & 7.9 \\
\hline
\end{tabular}

Mean \pm SD

the adsorption capacity of banana peel increased with decreasing medium $\mathrm{pH}$. Column study revealed the best fluoride removal conditions as: $10 \mathrm{mg} / \mathrm{L}$ initial fluoride concentration; flow rate $3.4 \mathrm{ml} / \mathrm{min}$, bed depth 3.5 and pH 5. The study results were best fitted with both Thomas and BDST models. Moreover, Thomas equation indicated that the increase in bed height caused an increase in the mass transport resistance and axial dispersion, which was confirmed from the $K_{\mathrm{Th}}$ values. The exhausted banana peel dust can be regenerated by $0.1 \mathrm{M} \mathrm{NaOH}$ and reused with minimal loss of efficiency for three adsorption-desorption cycles. Finally, best optimized conditions were applied for defluoridation of the field sample, and $86.5 \%$ removal was achieved. Therefore, it can be conclude that the use of banana peel as an adsorbent for fluoride removal is potentially cost-effective and may provide an alternative method for fluoride removal from contaminated water.
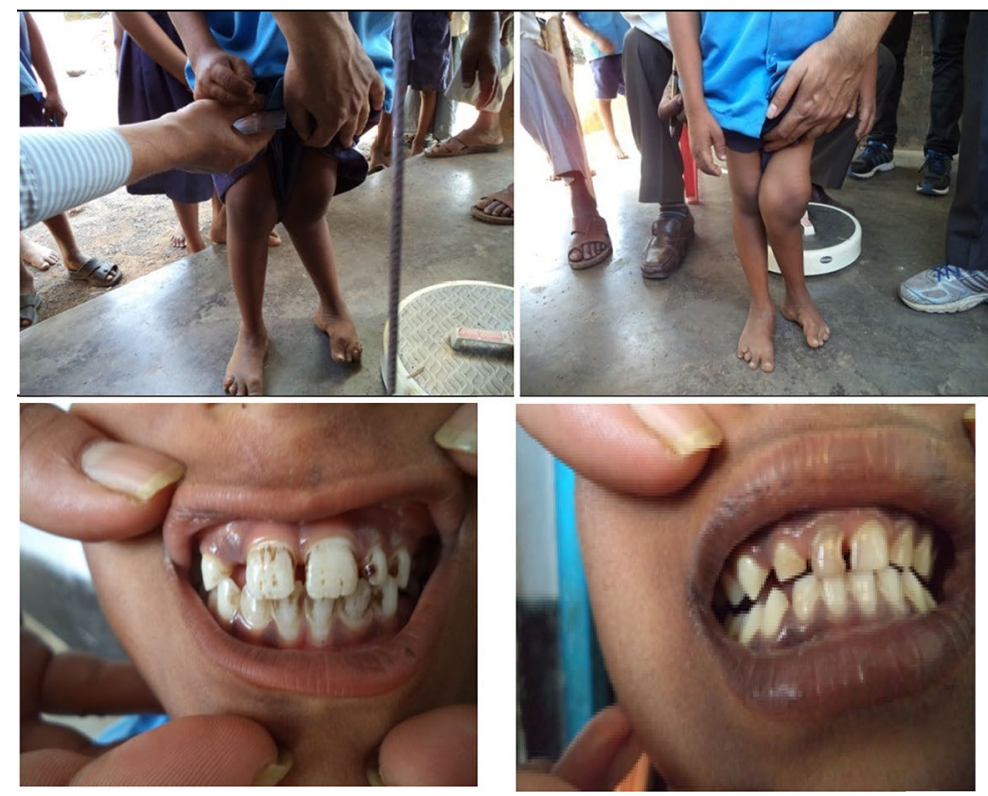
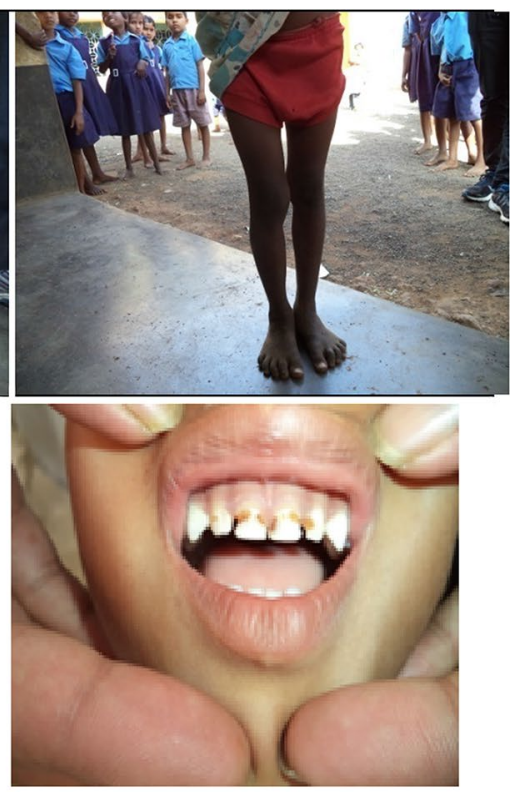

Fig. 9 Children affected by skletal and dental fluorosis in the study area 
Table 7 Comparative evaluation of adsorption capacities of various biosorbents for fluoride removal

\begin{tabular}{llll}
\hline Adsorbent & $\mathrm{pH}$ & $\begin{array}{l}\text { Adsorption capac- } \\
\text { ity (mg/g) }\end{array}$ & References \\
\hline $\begin{array}{l}\text { 1. Acid and alkali treated Tamarindous } \\
\quad \text { indica fruit shall }\end{array}$ & $2-10$ & - & Ramanjaneyulu et al. (2013) \\
2. Acid treated Banana peel & $2-12$ & 1.34 & Mohammad and Majumder (2014) \\
3. Untreated Tamarind fruit corner & $1-8$ & 4.14 & Sivasankar et al. (2012) \\
4. Mousabi (Citrus limetta) peel & 7.0 & 1.915 & Singh and Majumder (2015) \\
5. Ground nut (Arachishypogaea) & 7.0 & 1.15 & Singh and Majumder (2015) \\
6. Untreated sweet lemon peel & $2-12$ & 0.744 & Mohammad and Majumder (2014) \\
7. Untreated Banana peel (BPD-1) & $2-10$ & 17.43 & Bhaumik and Mondal (2014b) \\
8. Algal Biosorbent Spirogyra sp. & 2.0 & 1.272 & Mohan et al. (2007) \\
9. Leaf biomass powder sample & 2.0 & & Jamode et al.(2004) \\
10. Treated coffee husk & 2.0 & 0.416 & Getachew et al. (2015) \\
11. Guava seeds & - & 116.5 & Sánchez-Sánchez et al. (2013) \\
12. Banana peel & 5.0 & 8.15 & Present work \\
\hline
\end{tabular}

Acknowledgement The authors are grateful to Dr. Rajarshi Ghosh, Assistant Professor, Department of Chemistry, Burdwan University, Burdwan, West Bengal, India, for recording FTIR data and they also extend their gratitude to Dr. Srikanta Chakraborty, Incharge of SEM, USIC, University of Burdwan, West Bengal, India, for SEM study.

\section{Compliance with ethical standards}

Conflict of interest Authors declare that they have no conflict of interest for publishing the present manuscript.

Open Access This article is distributed under the terms of the Creative Commons Attribution 4.0 International License (http://creativeco mmons.org/licenses/by/4.0/), which permits unrestricted use, distribution, and reproduction in any medium, provided you give appropriate credit to the original author(s) and the source, provide a link to the Creative Commons license, and indicate if changes were made.

\section{References}

Al-Degs YS, Khraisheh MAM, Allen SJ, Ahmad MN (2009) Adsorption characteristics of reactive dyes in columns of activated carbon. J Hazard Mater 165:944-949

Bhaumik R, Mondal NK (2014a) Adsorption of fluoride from aqueous solution by a new low-cost adsorbent: thermally and chemically activated coconut fibre dust. Clean Techn Environ Policy. https:// doi.org/10.1007/s10098-015-0937-6

Bhaumik R, Mondal NK (2014b) Optimizing adsorption of fluoride from water by modified banana peel dust using response surface modelling approach. Appl Water Sci. https://doi.org/10.1007/ s13201-014-0211-9

Bhaumik R, Mondal NK, Das B, Roy P, Pal KC, Das C, Banerjee A, Dutta JK (2012) Eggshell powder as an adsorbent for removal of fluoride from aqueous solution: equilibrium, kinetic and thermodynamic studies. Eur J Chem 9(3):1457-1480

Bhaumik R, Mondal NK, Chattoraj S, Datta JK (2013) Application of response surface methodology for optimization of fluoride removal mechanism by newely developed biomaterial. Am J Anal Chem 4:404-419
Chen H, Yan M, Yang X et al (2012) Spatial distribution and temporal variation of high fluoride contents in groundwater and prevalence of fluorosis in humans in Yuanmou County, Southwest China. J Hazard Mater 235:201-209. https://doi.org/10.1016/j.jhazm at.2012.07.042

Dean HT (1934) Classification of mottled enamel diagnosis. J Am Dent Assoc 21:1421-1426

Death C, Coulson G, Kierdorf U, Kierdorf H, Morris WK, Hufschmid J (2015) Dental fluorosis and skeletal fluoride content as biomarkers of excess fluoride exposure in marsupials. Sci Total Environ 533:528-541

Deshmukh PD, Khadse GK, Shinde VM, Labhasetwar P (2017) Cadmium removal from aqueous solutions using dried banana peels as an adsorbent: kinetics and equilibrium modeling. J Bioremediat Biodegrad 8:395. https://doi.org/10.4172/2155-6199.1000395

Getachew T, Hussen A, Rao VM (2015) Defluoridation of water by activated carbon prepared from banana (Musa paradisiaca) peel and coffee (Coffea arabica) husk. Int J Environ Sci Technol 12:1857-1866

Ghosh SB, Bhaumik R, Mondal NK (2016) Optimization study of adsorption parameters for removal of fluoride using aluminiumimpregnated potato plant ash by response surface methodology. Clean Technol Environ Policy 18:1069-1083

Ghribi A, Chlendi M (2011) Modeling of fixed bed adsorption: application to the adsorption of an organic dye. Asian J Text 1:161-171

Goel J, Kadirvelu K, Rajagopal C, Garg VK (2005) Removal of lead (II) by adsorption using treated granular activated carbon: batch and column studies. J Hazard Mater B 125:211-220

Han R, Wang Y, Yu W, Zou W, Shi J, Liu H (2007) Biosorption of methylene blue from aqueous solution by rice husk in a fixedbed column. J Hazard Mater 141:713-718

Jamode AV, Sapkal VS, Jamode VS (2004) Defluoridation of water using inexpensive adsorbents. J Indian Inst Sci 84:163-171

Kierdorf H, Rhede D, Death C, Hufschmid J, Kierdorf U (2016) Reconstructing temporal variation of fluoride uptake in eastern grey kangaroos (Macropus giganteus) from a high-fluoride area by analysis of fluoride distribution in dentine. Environ Pollut 211:74-80

Koilraj P, Kannan S (2013) Aqueous fluoride removal using ZnCr layered double hyroxides and their polymeric composites: batch and column studies. Chem Eng J 234:406-415

Kumar J, Balomajumder C, Mondal P (2011) Application of agrobased biomasses for zinc removal from wastewater-a review. Clean Soil Air Water 39:641-652 
Ma W, Ya F, Wang R, Zhao YQ (2008) Fluoride removal from drinking water by adsorption using bone char as a biosorbent. Int J Environ Technol Manag 9:59-69

Memon JR, Memon SQ, Bhanger MI, Memon GZ, El-Turki A, Allen GC (2008) Characterization of banana peel by scanning electron microscopy and FT-IR spectroscopy and its use for cadmium removal. Colloids Surf B 66:260-265

Mohammad A, Majumder CB (2014) Removal of fluoride from synthetic waste water by using bioadsorbents. Int J Res Eng Technol 3(4):776-785

Mohan SV, Ramanaiah SV, Rajkumar B, Sarma PN (2007) Removal of fluoride from aqueous phase by biosorption onto algal biosorbent Spirogyra sp.-IO2: sorption mechanism elucidation. J Hazard Mater 141:465-474

Mohan D, Sharma R, Singh VK, Steele P, Pittman CU (2012) Fluoride removal from water using biochar, a green waste, low-cost adsorbent: equilibrium uptake and sorption dynamics modeling. Ind Eng Chem Res 51:900-914

Mondal MK (2010) Removal of Pb(II) from aqueous solution by adsorption using activated tea waste. Korean J Chem Eng 27(1):144-151

Mondal NK, Roy S (2015) Optimization study of adsorption parameters for removal of phenol on gastropod shell dust using response surface methodology. Clean Technol Environ Policy 18(2):429-447

Mondal NK, Das B, Bhaumik R, Bour T, Roy P (2012a) Calcareous soil as a promising adsorbent to remove fluoride from aqueous solution: equilibrium, kinetic and thermodynamic study. J Modern Chem Technol 3(3):1-21

Mondal NK, Bhaumik R, Bour T, Das B, Roy P, Datta JK (2012b) Studies on defluoridation of water by tea ash: an unconventional biosorbent. Chem Sci Trans 1(2):239-256

Mondal NK, Bhaumik R, Banerjee A, Datta JK, Baur T (2012c) A comparative study on the batch performance of fluoride adsorption by activated silica gel and activated rice husk ash. Int J Environ Sci 2(3): 1643-1661

Mondal NK, Das B, Bhaumik R, Bour T, Roy P (2012d) Calcareous soil as a promising adsorbent to remove fluoride from aqueous solution: equilibrium, kinetic and thermodynamic study. J Mod Chem Technol 3(3):1-21

Mondal NK, Bhaumik R, Roy P, Das B, Datta JK (2013) Investigation on fixed bed column performance of fluoride adsorption by sugarcane charcoal. J Environ Biol 34:1059-1064

Mondal NK, Bhaumik R, Datta JK (2015) Removal of fluoride by aluminum impregnated coconut fiber from synthetic fluoride solution and natural water. Alexan Eng J 54(4):1273-1284

Paudyal H, Pangeni B, Inoue K, Kawakita H, Ohto K, Alam S (2013) Adsorptive removal of fluoride from aqueous medium using a fixed bed column packed with $\mathrm{Zr}(\mathrm{IV})$ loaded dried orange juice residue. Biores Technol 146:713-720
Ramanjaneyulu V, Jaipal M, Yasovardhan N, Sharada S (2013) Kinetic studies on removal of fluoride from drinking water by using tamarind shell and pipal leaf powder. Inter J Emerg Trends Eng Develop 5(3):146-155

Sánchez-Sánchez HA, Cortés-Martínez R, Alfaro-CuevasVillanueva R (2013) Fluoride removal from aqueous solutions by mechanically modified guava seeds. Int J Sci Basic Appl Res 11(1):159-172

Shashi A, Kumar M, Bhardwaj M (2008) Incidence of skeletal deformities in endemic fluorosis. Trop Dr 38:231-233

Sheng PX, Ting Y, Chen JP, Hong L (2004) Sorption of lead, copper, cadmium, zinc and nickel by marine algal biomass: characterization of biosorptive capacity and investigation of mechanisms. J Colloid Interface Sci 275:131-141

Singh T, Majumder CB (2015) Kinetics for removal of fluoride from aqueous solution through adsorption from mousambi peel, ground nut shell and neem leaves. Inter J Sol Sci Engin Technol 3(4):879-883

Sivasankar V, Rajkumar S, Murugesh S, Darchen A (2012) Tamarind (Tamarindus indica) fruit shell carbon: a calcium-rich promising adsorbent for fluoride removal from groundwater. J Hazard Mater 225-226:164-172

Sulaiman A, Gupta AK, Basheer AB (2009) A fixed bed sorption system for defluoridation of ground water. J Urban Environ Eng 3(1):17-22

Susheela AK, Bhatnagar M (2002) Reversal of fluoride induced cell injury through elimination of fluoride and consumption of diet rich in essential nutrients and antioxidants. Mol Cell Biochem 234(235):335-340

Talnikar VD, Pant KK, Shukla NP (2004) A field study and continuous removal of fluoride in a packed column. J Environ Sci Eng 46(4):289-292

Tor A, Danaoglua N, Arslan G, Cengeloglu Y (2009) Removal of fluoride from water by using granular red mud: batch and column studies. J Hazard Mater 164:271-278

Vadivelan V, Kumar KV (2005) Equilibrium, kinetics, mechanism, and process design for the sorption of methylene blue onto rice husk. J Colloid Interf Sci 286:90-100

WHO (2011) Guideline for drinking-water quality, 4th edn. World Health Organization, Geneva

Zhu C, Lian Z, Wang Y, Shan X (2007) Removal of cadmium from aqueous solutions by adsorption on granular red mud (GRM). Sep Purif Technol 57:161-169

Publisher's Note Springer Nature remains neutral with regard to jurisdictional claims in published maps and institutional affiliations. 